\title{
Erratum to: Evaluation of myelin sheath and collagen reorganization pattern in a model of peripheral nerve regeneration using an integrated histochemical approach
}

\author{
Víctor Carriel $^{1} \cdot$ Ingrid Garzón $^{1} \cdot$ Miguel Alaminos $^{1} \cdot$ Antonio Campos $^{1}$
}

Published online: 20 April 2016

(C) Springer-Verlag Berlin Heidelberg 2016

\section{Erratum to: Histochem Cell Biol (2011) 136:709-717}

DOI 10.1007/s00418-011-0874-3

The authors would like to correct the term "crystal violet" to "cresyl violet" in the Materials and methods section, step 6 of the conventional LFB staining procedure.

The correct text should read as follows:

6. Counterstain in $0.1 \%$ aqueous solution of cresyl violet with $5 \mathrm{mg}$ oxalic acid for $10 \mathrm{~min}$ at $56{ }^{\circ} \mathrm{C}$.

The authors regret the error.

The online version of the original article can be found under doi:10.1007/s00418-011-0874-3.

Víctor Carriel

carriel.victor@gmail.com

1 Department of Histology (Tissue Engineering Group),

University of Granada, Avenida de Madrid 11,

18012 Granada, Spain 